\title{
Wit and Religion in the Time of Rabelais: Some Epigrams of Saint-Gelais
}

\author{
Donald Stone Jr. \\ (Harvard University)
}

Mellin de Saint-Gelais's reputation as exemplary practitioner of the epigram persisted well into the seventeenth and eighteenth centuries, ${ }^{1}$ but not beyond. Times change and so do tastes. As a result, to attempt a sympathetic discussion of those once-touted poems by Saint-Gelais we face the double need to call forth a wit that has been lost and to put aside new attitudes that have come into fashion. None of Saint-Gelais's epigrams illustrate better this challenge than those composed on a religious subject.

The poet's strategy in these poems varies little. He takes the characteristic of a particular religious phenomenon or figure and adapts it to the realm of the poet's worldly adventure with the beautiful but cruel beloved. Thus, Saint Sebastian, martyred by tyrants' arrows, mirrors the lover, martyred a thousand times by Cupid's arrows. ${ }^{2}$ Another quatrain alludes to a mystical experience of St. Francis of Assisi, who believed that Christ appeared to him in the form of an angel, imparting the stigmata to him. According to our poet, even without having seen in a dream or painting "Une plus qu'Ange et Seraphin, " he nevertheless suffers a wound that will be the end of him (II, 23).

It is hard to imagine that the interest generated by these poems extended beyond an appreciation for Mellin's ability to find analogies where one might least expect them. Yet that is not an unuseful observation, as it could be said to explain a wide swath of poems penned by Saint-Gelais. The pieces in a chess game (I, 278), the cardinal features of an almanac (I, 259), the splitting of the soundboard of a guitar (I, 234) are only some of the distinctly ordinary items Saint-Gelais managed to weave into the fabric of his verse.

In other of Saint-Gelais's epigrams, however, a modern eye might be tempted to espy more subtle strategies. Consider this quatrain on St. Claire. In reaction 
to a portrait of the saint offering her heart to God, who, in turn, extends a bouquet of flowers, Saint-Gelais composed this epigram:

Si ceste histoire n'est point feincte,

Je puis esperer estre saincte;

Car mon coeur, de bon coeur donné

N'est rien que de fleurs guerdonné. (II, 20)

The surface is straightforward enough. Since, like Claire, the lover has given his heart and received only flowers in return, he can aspire to becoming a saint. But is "saint" perhaps not used derisively, standing for a person who accepts to forego the physical pleasures of this life? And is this reading not reinforced by the opening salvo: "Si ceste histoire n'est point feincte" (as if to imply the improbability of it all)? And what of the poet's close? It is possible to read in the contrast between "mon coeur, de bon coeur donné" and "N'est rien que de fleurs guerdonné" more than a slight note of petulance: "What a paltry return for the gift of a heart?" Moreover, is there not the possibility that the petulance applies not only to the love story but also to God's response to Claire's sacrificial gesture?

A huitain on All Souls' Day urges the lady not to pray for the dead: "Vous avez trop dequoy faire oraison/Pour ceux qu'avez de ce monde chassés" (II, 63). They are many, the poet observes, languishing in purgatory. "Mais je suis pis, si vous ne pourchassez / Qu'en cest enfer on ayt de moy memoire." Again some predictable playing with terms. The purgatory and hell in question are in this world and the dead that Saint-Gelais wants commemorated are those the lady has "dispatched" in the usual haughty ways. Nothing scandalous, perhaps, unless we decide that in the process of writing about love, the poet has taken the religious significance of All Souls' Day and subverted its meaning. The Church asks us to remember on that day those who are gone; this Saint-Gelais would have the lady cease doing in favor of a very different, very secular commemoration.

Yet another huitain of note is inspired by St. James.

Si Dieu nous faisoit devenir

Pelerins à quelque pardon,

Je ne saurois rien retenir,

Escharpe, manteau, ne bourdon,

Que ne misse à vostre abandon. ${ }^{3}$ (II, 77)

However, as a fair recompense, he adds, "Bien voudrois-je . . ./ Fouiller en 
vostre panetiere." The "pointe" lies, of course, in that last word which signifies both the sack in which a pilgrim took food for his trip and a far more anatomical lunch. Once again, then, a religious concept (here, the search for "pardon") has been played with and again it has been transformed into something both different from and antithetical to the religious idea in question.

For readers familiar with the sixteenth century and especially with past criticism on Rabelais, such suspicions about a possible assault on the integrity of religion will come as no surprise. The author of Gargantua and Pantagruel, too, was once considered to have deliberately engaged in subverting the Christian religion. Arguments against that interpretation have become commonplace in Rabelais studies, where the capacity of modern anticlerical thinking to impose itself on the past is now fully recognized. I believe that it is possible to say as much regarding an anti-Christian interpretation of these epigrams by Saint-Gelais.

These epigrams remind us in their fashion that, as Lucien Febvre phrased it, the period was "saturated with religion." 4 The titles of many epigrams by Saint-Gelais suggest that the image of the saints referred to is found in the lady's Book of Hours, a possession that returns many times among the epigrams and among Mellin's poems in general. 5 The epigrams, we realize, are expected to evoke familiar pictures of familiar individuals, with familiar traits and attributes. But more important still is the reminder here that the poet has transposed sacred wounds and arrows and martydoms to the domain of love in order to exploit that same preponderant role that religion played in his society. For these epigrams to succeed, we must assume the very opposite of deflation of or attacks upon the religious material in question. Were the pain or ecstasy of the saints a mere sham, there would be no point in linking them to the poet's own experience. If the celebration of the dead had no significance, Saint-Gelais would have no reason to urge the lady to reenact that commemoration.

A poem of wit and surprise, the epigram often achieves its effect through an unexpected crossing of levels or, as we have already noted, through the juxtaposition of unexpected analogies. Here again is the opening of the epigram on pilgrimages:

Si Dieu nous faisoit devenir

Pelerins à quelque pardon,

Je ne saurois rien retenir, 
Escharpe, manteau, ne bourdon,

Que ne misse à vostre abandon.

Nothing in the verses is untoward. The vocabulary remains consistent throughout and the "I" participates willingly in the spirit of the religious undertaking. Yet before we know it, this poem about gifts produces a gross pun. We laugh because a straightforward poem about a religous journey suddenly turns a person's search for life eternal into the poet's pursuit of a moment horizontal. That the phenomena pilgrimages and indulgences have been compromised by this procedure is, I think, far from obvious.

Of course, it is no good trying to make a case for the poetic qualities of these epigrams. Cleverness does not equal beauty. These poems do, however, contain significant lessons for us regarding wit and religion in a distant period, lessons we may not entirely grasp, but without which a fair assessment of the function of these epigrams in their time will remain even further beyond our reach.

1 In his Traitté de l'épigramme (1658), G. Colletet called Mellin, "l'Esprit le plus raffiné dans la Science Epigrammatique" (ed. P. A. Jannini, Geneva, 1965, p. 46). To appreciate French borrowings from the Greek Anthology, J.-B.-G. D'Ansse de Villoison (1753-1805) recommended to a friend that he read Mellin and Vauquelin de la Fresnaye. (See James Hutton, The Greek Anthology in France, Ithaca, 1946, p. 556.)

2 See the quatrain "A ce Martyr plus qu'autre je ressemble" (II, 17). All quotations are from the Oeuvres complètes de Melin de Sainct-Gelays, ed. P. Blanchemain, Paris, 1873, 3 vols.

3 "At your disposal."

4 Lucien Febvre, Le Problème de l'incroyance au XVIe siècle: la religion de Rabelais (Paris, 1962), p. 370.

5 See, for example, II, 13, 17-27, 47; I, 262, 268. 